Вацький В. Ф., кандидат сільськогосподарських наук, Величко С. А., аспірант *

Полтавська державна аграрна академія

\title{
МОЛОЧНА ПРОДУКТИВНІСТЬ КОРІВ УКРАЇНСЬКОЇ ЧЕРВОНО-РЯБОЇ МОЛОЧНОЇ ПОРОДИ ЗАЛЕЖНО ВІД ЇХ ВІДТВОРЮВАЛЬНОЇ ЗДАТНОСТІ
}

\section{Рецензент - кандидат сільськогосподарських наук О. О. Держсговський}

\begin{abstract}
Вивчено особливості зв 'язку молочної продуктивності та відтворювальної здатності корів украӥнської червоно-рябої молочної породи. Встановлено, щзо з підвищенням рівня молочної продуктивності відтворювальна здатність корів погіршується.

Визначено, щзо оптимальний сервіс-період знаходиться в межах 51-90 днів; для високопродуктивних корів тривалість сервіс-періоду до 121 дня не критична. Запропоновано показник, щчо характеризує рівень молочної продуктивності корів із урахуванням їх відтворювальної здатності. Результати досліджень дають можливість поліпшити використання молочної худоби в господарстві иляхом правильної організації відтворення стада.
\end{abstract}

Ключові слова: молочна продуктивність, відтворювальна здатність, сервіс-період, міжотельний період (МОП), коефіцієнт відтворювальної здатності (КВЗ), кореляиія.

Постановка проблеми. Підвищення молочної продуктивності корів - основне завдання селекції в молочному скотарстві, виконання якого залежить від багатьох факторів, у тому числі й від відтворювальної здатності молочної худоби. Знання закономірностей зв'язку показників молочної продуктивності із показниками відтворювальної здатності робить можливим раціональне ведення молочного скотарства й отримання господарством максимально можливого прибутку.

Аналіз основних досліджень і публікацій, у яких започатковано розв'язання проблеми. Як показує досвід, українська червоно-ряба молочна порода $є$ однією 3 високопродуктивних i економічно вигідних порід великої рогатої худоби, яка знаходиться на стадії консолідації генотипової структури, підвищення молочної продуктивності, поліпшення відтворювальної здатності, удосконалення типу тілобудови тварин.

Зростання продуктивності корів української червоно-рябої породи можливе лише за поєднання нарощування генетичного потенціалу засобами сучасної селекції та біотехнології із біо- логічно й господарсько обгрунтованими умовами утримання та експлуатації [1].

Одним із важливих показників пристосованості тварин до технологічних умов $є$ їх відтворювальна здатність. Вона характеризує спільну спрямованість (однонаправленість чи різноспрямованість) штучного і природного відбору у стаді.

Для оцінки відтворювальної здатності корів найчастіше використовують показник тривалості міжотельного періоду. Оптимальний міжотельний період (365 днів) включає в себе сервісперіод (80 днів) і період тільності (285 днів), які характеризують відтворювальну здатність корів. Оскільки тривалість тільності $\epsilon$, в основному, величиною постійною, то в практичних цілях для характеристики відтворювальної здатності корів використовують показник тривалості сервіс-періоду.

Паралельно 3 показниками відтворювальної здатності, міжотельний період включає в себе лактаційний період (305-320 днів) і період сухостою (45-60 днів), які характеризують молочну продуктивність корів $[2,6]$.

Нежданов А. [4] вважає, що для реалізації генетичного потенціалу молочної продуктивності слід враховувати й інтенсивність використання маточного поголів'я у відтворенні. Так, для економічного ведення галузі молочного скотарства та інтенсивного відтворення стада корова повинна народжувати одне теля в рік, - за умови настання наступної тільності через 2-3 місяці після отелення [2, 6].

На думку Сірацького Й. та ін. [5], відтворювальну здатність і молочну продуктивність корів доцільно враховувати в сукупності, як взаємообумовлюючі фактори. Їх дослідження показали, що у корів із надоями 3-6 тис. кг молока за лактацію сервіс-період триває 60-102 дні. У разі вищих надоїв на кожні 1000 кг молока за лактацію тривалість сервіс-періоду збільшується на 14-22 дні.

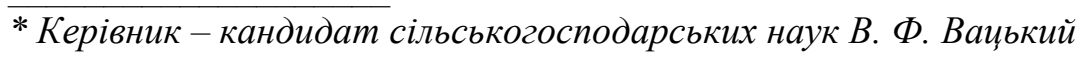


Водночас існування чималої кількості високопродуктивних корів-рекордисток із високими показниками відтворювальної здатності свідчать про селекційну можливість поєднання даних ознак.

Мета і завдання досліджень. Вивчення особливостей зв'язку показників молочної продуктивності корів із показниками їх відтворювальної здатності.

Відповідно до мети, перед нами постали завдання: вивчити особливості молочної продуктивності та відтворювальної здатності корів української червоно-рябої молочної породи; виявити закономірності зв'язку показників молочної продуктивності корів із показниками їх відтворювальної здатності, встановити оптимальні величини, які їх характеризують; провести пошук показника, який би одночасно враховував рівень молочної продуктивності корів у поєднанні з рівнем їх відтворювальної здатності.

Матеріал і методи досліджень. Дослідження проведені на основі даних господарського і племінного обліку за 1999-2011 роки по стаду корів української червоно-рябої молочної породи СВК «Батьківщина» Котелевського району Полтавської області. Племінний облік у господарстві проводиться за допомогою системи управління молочним скотарством «Орсек». Для проведення досліджень враховували тривалість лактації, надій за лактацію, надій за 305 днів або вкорочену лактацію (але не менше 240 днів), вміст та кількість жиру в молоці, тривалість тільності, сервісперіоду, міжотельного періоду, індекс осіменінь, коефіцієнт відтворної здатності.

Коефіцієнт відтворної здатності визначали за формулою:

$$
K B 3=\frac{365}{M O \Pi},
$$

де: КВЗ - коефіцієнт відтворної здатності;

МОП - період між отеленнями;

365 - кількість днів року.

Біометричну обробку одержаних даних проводили згідно з методикою Є. К. Меркур'євої [3] на ПЕОМ із використанням програмного забезпечення Microsoft Excel 2007.

Результати досліджень. Молочна продуктивність корів дослідного стада знаходиться на досить високому рівні (4258 кг молока за 305 днів лактації, вміст жиру - 3,81 \%), але їх відтворювальна здатність $є$ проблемою (тривалість сервісперіоду дорівнює 130 днів, міжотельного - 410, а вихід телят - 89 \%) (табл. 1). Таку ж закономірність відмічає Й. Сірацький та ін. [5] стосовно високопродуктивних новостворених порід молочної худоби.

Для характеристики рівня молочної продуктивності з урахуванням відтворювальної здатності корів ми застосували показник середньодобового надою на один день міжотельного періоду.

У процесі обробки й аналізу даних визначалося, як залежить молочна продуктивність і відтворювальна здатність корів від тривалості сервіс-періоду, - показника, що характеризує фізіологічні можливості відтворювальної здатності та визначає тривалість лактації корів (табл. 1).

У результаті проведених досліджень ми прийшли до висновку, що оптимальним сервіс-періодом можна вважати період 51-90 днів, який дозволяє отримувати одне теля на корову в рік (середній МОП становить 351 день) і підтримувати високу молочну продуктивність (4114 кг за 305 днів лактаціi). 3 таким сервіс-періодом усі показники молочної продуктивності й відтворювальної здатності знаходяться на високому рівні, а від 100 корів за рік можна отримати 104 телят. Це підтверджується й найвищим рівнем середньодобового надою на один день міжотельного періоду.

Скорочення сервіс-періоду нижче оптимального призведе до скорочення тривалості лактації та зниження молочної продуктивності, а збільшення сервіс-періоду - до іiі підвищення. Однак у цьому випадку відмічається погіршення відтворювальної здатності, що проявляється у підвищенні індексу осіменінь, зниженні КВ3, збільшенні міжотельного періоду, i, як наслідок, призводить до зниження виходу телят, вибракування корів через яловість та зниження економічної ефективності ведення молочного скотарства.

Молочна продуктивність і відтворювальна здатність корів характеризується багатьма показниками, основними з яких є тривалість лактації, надій за лактацію, вміст жиру в молоці, тривалість сервіс- і міжотельного періодів та інші. Рівень зв'язку між цими показниками (визначений методами кореляційного й дисперсійного аналізу) наведено в таблиці 2.

Так, встановлено існування високої позитивної залежності надою $(\mathrm{r}=0,73, \mathrm{P}>0,999)$ та кількості молочного жиру (r=0,71, $\mathrm{P}>0,999)$ від тривалості лактації; кількості молочного жиру від надою за лактацію ( $\mathrm{r}=0,98, \mathrm{P}>0,999)$. При цьому тривалість лактації визначає 39 \% мінливості надою та 38 \% мінливості кількості молочного жиру, а надій за лактацію - 71 \% мінливості кількості молочного жиру. Достовірна кореляція встановлена між вмістом жиру в молоці та його кількістю ( $\mathrm{r}=0,19$, $\mathrm{P}>0,999)$. Нами не виявлено зв'язку вмісту жиру в молоці з надоєм, тривалістю лактації й показника- 
ми відтворювальної здатності. Це свідчить про те, що на жирність молока впливають інші фактори, наприклад, спадковість, рівень годівлі та якісний склад раціонів.

\section{1. Залежність молочної продуктивності та відтворювальної здатності від тривалості сервіс-періоду}

\begin{tabular}{|c|c|c|c|c|c|c|}
\hline \multicolumn{2}{|c|}{ Тривалість сервіс-періоду, днів } & до 50 & $51-90$ & $91-130$ & $\begin{array}{c}131 \\
\text { і більше } \\
\end{array}$ & $\begin{array}{l}\text { У серед- } \\
\text { ньому }\end{array}$ \\
\hline \multicolumn{2}{|l|}{$\mathrm{n}$} & 283 & 539 & 346 & 667 & 1835 \\
\hline Середня тривалість & $\mathrm{M}$ & 37,34 & 70,42 & 109,01 & 227,78 & 129,79 \\
\hline сервіс-періоду, днів & $\pm \mathrm{m}$ & $\pm 0,54$ & $\pm 0,47$ & $\pm 0,62$ & $\pm 3,98$ & $\pm 2,32$ \\
\hline $\begin{array}{c}\text { Міжотельний період (МОП), } \\
\text { днів }\end{array}$ & $\begin{array}{c}\mathrm{M} \\
\pm \mathrm{m}\end{array}$ & $\begin{array}{l}318,48 \\
\pm 0,69\end{array}$ & $\begin{array}{c}351,32 \\
\pm 0,51\end{array}$ & $\begin{array}{c}389,30 \\
\pm 0,73\end{array}$ & $\begin{array}{c}507,91 \\
\pm 3,98\end{array}$ & $\begin{array}{c}410,34 \\
\pm 2,31\end{array}$ \\
\hline $\begin{array}{c}\text { Коефіцієнт відтворної } \\
\text { здатності (КВ3) }\end{array}$ & $\begin{array}{c}\mathrm{M} \\
\pm \mathrm{m}\end{array}$ & $\begin{array}{c}1,15 \\
\pm 0,00\end{array}$ & $\begin{array}{c}1,04 \\
\pm 0,00\end{array}$ & $\begin{array}{c}0,94 \\
\pm 0,00\end{array}$ & $\begin{array}{c}0,72 \\
\pm 0,00\end{array}$ & $\begin{array}{c}0,89 \\
\pm 0,00\end{array}$ \\
\hline Тривалість тільності, днів & $\begin{array}{c}\mathrm{M} \\
\pm \mathrm{m}\end{array}$ & $\begin{array}{c}281,21 \\
\pm 0,38\end{array}$ & $\begin{array}{c}280,90 \\
\pm 0,26\end{array}$ & $\begin{array}{c}280,41 \\
\pm 0,30\end{array}$ & $\begin{array}{c}280,28 \\
\pm 0,30\end{array}$ & $\begin{array}{c}280,63 \\
\pm 0,16\end{array}$ \\
\hline Індекс осіменінь & $\begin{array}{c}\mathrm{M} \\
\pm \mathrm{m}\end{array}$ & $\begin{array}{l}1,17 \\
\pm 0,03\end{array}$ & $\begin{array}{c}1,54 \\
\pm 0,03\end{array}$ & $\begin{array}{c}2,08 \\
\pm 0,05\end{array}$ & $\begin{array}{c}3,45 \\
\pm 0,08\end{array}$ & $\begin{array}{c}2,28 \\
\pm 0,04\end{array}$ \\
\hline Тривалість лактації, днів & $\begin{array}{c}\mathrm{M} \\
\pm \mathrm{m}\end{array}$ & $\begin{array}{c}265,96 \\
\pm 0,88\end{array}$ & $\begin{array}{c}292,91 \\
\pm 0,76\end{array}$ & $\begin{array}{c}327,62 \\
\pm 1,20\end{array}$ & $\begin{array}{l}435,16 \\
\pm 3,95\end{array}$ & $\begin{array}{c}347,01 \\
\pm 2,19\end{array}$ \\
\hline Надій за лактацію, кг & $\begin{array}{c}\mathrm{M} \\
\pm \mathrm{m}\end{array}$ & $\begin{array}{l}3688,58 \\
\pm 53,16 \\
\end{array}$ & $\begin{array}{l}4131,08 \\
\pm 39,67\end{array}$ & $\begin{array}{c}4480,12 \\
\pm 57,20\end{array}$ & $\begin{array}{c}5692,48 \\
\pm 64,70\end{array}$ & $\begin{array}{c}4696,20 \\
\pm 34,78\end{array}$ \\
\hline Надій за 305 днів лактації, кг & $\begin{array}{c}\mathrm{M} \\
\pm \mathrm{m}\end{array}$ & $\begin{array}{l}3686,42 \\
\pm 53,05\end{array}$ & $\begin{array}{c}4113,81 \\
\pm 39,07\end{array}$ & $\begin{array}{c}4321,24 \\
\pm 54,04\end{array}$ & $\begin{array}{l}4584,91 \\
\pm 36,74\end{array}$ & $\begin{array}{l}4258,25 \\
\pm 23,08\end{array}$ \\
\hline $\begin{array}{c}\text { Середньодобовий надій за } \\
\text { лактацію, кг }\end{array}$ & $\begin{array}{c}\mathrm{M} \\
\pm \mathrm{m}\end{array}$ & $\begin{array}{l}13,86 \\
\pm 0,19\end{array}$ & $\begin{array}{l}14,09 \\
\pm 0,13\end{array}$ & $\begin{array}{l}13,67 \\
\pm 0,17\end{array}$ & $\begin{array}{l}13,14 \\
\pm 0,10\end{array}$ & $\begin{array}{l}13,63 \\
\pm 0,07\end{array}$ \\
\hline $\begin{array}{c}\text { Середньодобовий } \\
\text { надій на } 1 \text { день МОП, кг }\end{array}$ & $\begin{array}{c}\mathrm{M} \\
\pm \mathrm{m}\end{array}$ & $\begin{array}{l}11,58 \\
\pm 0,16\end{array}$ & $\begin{array}{l}11,76 \\
\pm 0,11\end{array}$ & $\begin{array}{l}11,51 \\
\pm 0,15\end{array}$ & $\begin{array}{l}11,23 \\
\pm 0,10\end{array}$ & $\begin{array}{l}11,49 \\
\pm 0,06\end{array}$ \\
\hline Вміст молочного жиру, \% & $\begin{array}{c}\mathrm{M} \\
\pm \mathrm{m}\end{array}$ & $\begin{array}{c}3,80 \\
\pm 0,02\end{array}$ & $\begin{array}{c}3,81 \\
\pm 0,01\end{array}$ & $\begin{array}{c}3,82 \\
\pm 0,01\end{array}$ & $\begin{array}{c}3,81 \\
\pm 0,01\end{array}$ & $\begin{array}{c}3,81 \\
\pm 0,01\end{array}$ \\
\hline
\end{tabular}

2. Зв'язок показників молочної продуктивності з показниками відтворювальної здатності

\begin{tabular}{|c|c|c|c|}
\hline Показники А-В & $\mathrm{r} \pm \mathrm{m}_{\mathrm{r}}$ & $\begin{array}{c}\text { Частка впливу } \\
\mathrm{A} \mathrm{на} \mathrm{В,} \%\end{array}$ & $\mathrm{P} \geq$ \\
\hline Тривалість лактації - надій за лактацію & $0,73 \pm 0,01$ & 39 & 0,999 \\
\hline Тривалість лактації - вміст жиру & $-0,02 \pm 0,02$ & 0 & - \\
\hline Тривалість лактації - кількість жиру & $0,71 \pm 0,01$ & 38 & 0,999 \\
\hline Надій за лактацію - вміст жиру & $0,01 \pm 0,02$ & 0 & - \\
\hline Надій за лактацію - кількість жиру & $0,98 \pm 0,00$ & 71 & 0,999 \\
\hline Вміст жиру - кількість жиру & $0,19 \pm 0,02$ & 4 & 0,999 \\
\hline $\begin{array}{c}\text { Тривалість сервіс-періоду - } \\
\text { тривалість міжотельного періоду }\end{array}$ & $1,00 \pm 0,00$ & 71 & 0,999 \\
\hline Тривалість сервіс-періоду - тривалість тільності & $-0,07 \pm 0,02$ & 0 & 0,99 \\
\hline $\begin{array}{c}\text { Тривалість тільності - } \\
\text { тривалість міжотельного періоду }\end{array}$ & $0,00 \pm 0,02$ & 0 & - \\
\hline Індекс осіменінь -тривалість сервіс-періоду & $0,63 \pm 0,01$ & 32 & 0,999 \\
\hline Тривалість сервіс-періоду - тривалість лактації & $0,96 \pm 0,00$ & 65 & 0,999 \\
\hline Тривалість сервіс-періоду - надій за лактацію & $0,69 \pm 0,01$ & 34 & 0,999 \\
\hline Тривалість сервіс-періоду - вміст жиру & $-0,02 \pm 0,02$ & 0 & - \\
\hline $\begin{array}{c}\text { Тривалість лактації- } \\
\text { тривалість міжотельного періоду }\end{array}$ & $0,96 \pm 0,00$ & 67 & 0,999 \\
\hline $\begin{array}{c}\text { Надій за лактацію - } \\
\text { тривалість міжотельного періоду }\end{array}$ & $0,69 \pm 0,01$ & 32 & 0,999 \\
\hline
\end{tabular}


СІЛЬСЬКЕ ГОСПОДАРСТВО. ТВАРИННИЦТВО

3. Молочна продуктивність і відтворювальна здатність корів залежно від рівня надою на один день міжотельного періоду

\begin{tabular}{|c|c|c|c|}
\hline Показник & M- & $\mathrm{M}_{0}$ & $\mathrm{M}+$ \\
\hline $\mathrm{n}$ & 544 & 746 & 545 \\
\hline $\begin{array}{c}\text { Надій на один день міжотельного } \\
\text { періоду, кг }\end{array}$ & $8,48 \pm 0,06$ & $11,48 \pm 0,03$ & $14,51 \pm 0,06$ \\
\hline Тривалість лактації, днів & $343,42 \pm 4,06$ & $350,17 \pm 3,47$ & $346,25 \pm 3,90$ \\
\hline Надій за лактацію, кг & $3534,82 \pm 45,85$ & $4726,45 \pm 41,92$ & $5814,03 \pm 59,70$ \\
\hline Середньодобовий надій за лактацію, кг & $10,34 \pm 0,08$ & $13,61 \pm 0,04$ & $16,94 \pm 0,07$ \\
\hline Надій за 305 днів лактації, кг & $3217,95 \pm 27,99$ & $4273,22 \pm 18,59$ & $5276,14 \pm 26,93$ \\
\hline Вміст молочного жиру, \% & $3,80 \pm 0,01$ & $3,81 \pm 0,01$ & $3,82 \pm 0,01$ \\
\hline Кількість молочного жиру, кг & $134,20 \pm 1,77$ & $179,87 \pm 1,62$ & $222,03 \pm 2,34$ \\
\hline Тривалість сухостійного періоду, днів & $72,14 \pm 1,40$ & $61,73 \pm 0,74$ & $55,31 \pm 0,67$ \\
\hline Індекс осіменінь & $2,29 \pm 0,07$ & $2,37 \pm 0,06$ & $2,14 \pm 0,06$ \\
\hline Тривалість сервіс-періоду, днів & $136,07 \pm 4,50$ & $131,48 \pm 3,62$ & $121,21 \pm 3,98$ \\
\hline Тривалість тільності, днів & $280,90 \pm 0,26$ & $280,62 \pm 0,20$ & $280,38 \pm 0,36$ \\
\hline Тривалість міжотельного періоду, днів & $416,93 \pm 4,51$ & $411,97 \pm 3,61$ & $401,52 \pm 3,97$ \\
\hline $\begin{array}{c}\text { Коефіцієнт відтворювальної здатності } \\
\text { (КВ3) }\end{array}$ & $0,88 \pm 0,01$ & $0,89 \pm 0,01$ & $0,91 \pm 0,01$ \\
\hline
\end{tabular}

Відтворювальну здатність корів найкраще характеризують показники тривалості сервіс- i міжотельного періодів, кореляція між якими становить 1,00 (P>0,999). Тривалість сервісперіоду визначає $71 \%$ мінливості тривалості міжотельного періоду. Тому на практиці для характеристики відтворювальної здатності корів найчастіше використовують сервіс-період. Встановлено, що на тривалість сервіс-періоду впливає індекс осіменінь $(\mathrm{r}=0,63, \mathrm{P}>0,999)$, визначаючи $32 \%$ його мінливості. Тож поліпшити відтворювальну здатність корів можливо шляхом створення комфортних умов догляду й утримання для максимального прояву статевої охоти, регулярного іiі виявлення, визначення оптимального часу осіменіння і скорочення кількості осіменінь на одне запліднення.

Iз подовженням сервіс-періоду тварина запасає більше енергії в організмі й використовує ії для подальшої лактації, що проявляється у підвищенні молочної продуктивності та тривалості лактації. Сервіс-період обумовлює 65 \% мінливості тривалості лактації $(\mathrm{r}=0,96, \mathrm{P}>0,999)$ і $34 \%$ мінливості надою за лактацію $(\mathrm{r}=0,69, \mathrm{P}>0,999)$.

$\mathrm{y}$ цілому можемо зробити висновок, що з покращанням молочної продуктивності погіршується відтворювальна здатність корів. Тому доцільно знайти «золоту середину», яка буде економічно вигідною для господарства і фізіологічною для тварин.

Для цього найкраще підходить показник середньодобового надою на один день міжотельного періоду, який враховує рівень молочної продук- тивності корів у поєднанні з їх відтворювальною здатністю. На основі нього ми поділили всіх корів на три групи. Перша група мала низькі показники $(\mathrm{M}<0,5 \sigma)$, друга - середні $(\mathrm{M} \pm 0,5 \sigma)$, третя - високі (М>0,5б) (табл. 3).

Так, використання показника середньодобового надою на один день міжотельного періоду дає змогу виявити кращих за продуктивністю корів iз високими показниками їх відтворювальної здатності. У нашому випадку використання цього показника дало можливість встановити, що для високопродуктивних корів української червоно-рябої молочної породи (5276 кг молока за 305 днів лактації) тривалість сервіс-періоду 121 день (МОП=402 дні) не критична: вона дає змогу отримувати високі надої молока при достатньому рівні відтворення стада (вихід телят дорівнює 91 \%). Отже, для подальшого відтворення стада доцільно відбирати корів із рівнем середньодобового надою на один день міжотельного періоду 14,5 кг і більше.

\section{Висновки:}

1. Раціональне використання молочної худоби має базуватися на знанні біологічних закономірностей функціонування живого організму. До таких закономірностей відносяться й закономірності зв'язку показників молочної продуктивності із показниками відтворювальної здатності худоби.

2. Молочна продуктивність корів тісно пов'язана 3 їх відтворювальною здатністю: 3 підвищенням молочної продуктивності корів їх від- 
творювальна здатність у цілому погіршується. Проявляється це в збільшенні тривалості сервісперіоду, міжотельного періоду та індексу осіменінь, що негативно впливає на економічну ефективність ведення молочного скотарства. Нами встановлено, що оптимальний сервіс-період становить 51-90 днів, це дає змогу щороку отриму-

\section{БІБЛІОГРАФІЯ}

1. Бородай I. C. До історії виведення української червоно-рябої молочної породи корів / Бородай I. С. // Вісник аграрної науки. - 2003. - №11. C. 71-74.

2. Гончаренко I. В. Молочна продуктивність голштинських корів 3 подовженою лактацією / Гончаренко I. В. // Науковий вісник НАУ. 2002. - Вип. 50. - С. 161-168.

3. Меркурьева Е. К. Биометрия в селекции и генетике сельскохозяйственных животных. - М. : Колос, 1970. -423 с.

4. Нежданов А. Интенсивность воспроизводства вати одне теля і більше від кожної корови. Для високопродуктивних корів тривалість сервісперіоду до 121 дня не є критичною.

3. Досить інформативним показником $€$ середньодобовий надій на 1 день міжотельного періоду, який характеризує молочну продуктивність корів у зв'язку з їх відтворювальною здатністю.

и молочная продуктивность коров / Нежданов А., Сергеева Л., Лободин К. // Молочное и мясное скотоводство. - 2008. - №5. - С. 2-4.

5. Сірацький Й. Пошуки резервів відтворення BPX: здобутки і перспективи / Сірацький Й., Демчук С. [та ін.] // Пропозиція. - 2005. - №1. C. $110-112$.

6. Тараненко С. В. Відтворювальна здатність корів південного типу української чорно-рябої молочної породи ДПДГ «Асканійське» / Тараненко С. В. // Науковий вісник «Асканія-Нова». - 2008. Вип. 1. - С. 34-39. 